\title{
Perma-dying Worlds and the Limit of Eternal Return in Digital Games
}

\section{Eleonora Imbierowicz}

University of Wrocław | eleonora.imbierowicz@uwr.edu.pl ORCID: 0000-0002-8939-2332

\begin{abstract}
The article discusses the types of death in selected digital and tabletop games, sorting them into two groups: ones that follow the pattern of eternal return and allow the player to endlessly respawn in their worlds, and ones that limit the possibility of coming back. The article focuses on the latter, and analyses the mechanics limiting the access to the game from permadeath, through the randomness and unique character of the events happening in online multiplayer games, up to permapermadeath and the effects of the application of these mechanics.
\end{abstract}

Keywords: permapermadeath, permadeath, eternal recurrence, mechanics of death 



\section{Premise}

This article aims to discuss the advent of permapermadeath and other game mechanics that limit the possibility of replaying the game as opposed to more frequently used game mechanics that grant the player the possibility of endless resurrections.

\section{Playing, dying, coming back, changing}

The eternal return was one of the main ideas in the philosophy of Friedrich Nietzsche. He proposed a vision of the world endlessly repeating itself, featuring ceaseless reconfigurations and reappearances. It was a comforting idea, especially in the face of the fall of the God-given promise of an afterlife. The new power of mankind, and, as some say, of Nietzsche's Übermensch, was derived from the knowledge that time is circular (Loeb, 2010, p. 9). A man knowing that everything will come back earns control over the present moment and all its future incarnations.

The demiurgic ability of humankind to create new worlds - in literature, in film, in art - reached a new level in the second half of the 2oth century with the emergence of video games. And they are, indeed, worlds through which we travel endlessly. They repeat themselves for every other player and the player repeats each passage and each event as many times as they may possibly want.

The process of re-playing was problematised by Piotr Kubiński (2016), who claimed that plot-based games are inherently unfinished and constantly open to changes (p. 140). Kubiński describes a passage from The Witcher in which the player is surprised by an unavoidable fight with a beast. If they die, they can come back and, knowing about the upcoming battle, prepare for the challenge and win. Two versions of the same passage overlap and the player ultimately chooses one of them to be a part of a final story. Kubiński's term for overlapping narratives is the palimpsest trial. He argues that the two versions of the events do not only overlap but also interfere with each other - as it was the previous failure that made the player prepare while playing for the second time and, ultimately, win (pp. 137-147). 
A lot has been said about the processes of multiple repetitions. In his essay Beyond the Pleasure Principle, Sigmund Freud, previously certain that our lives are governed solely by seeking pleasure and avoiding pain, described a drive to repeat traumatic experiences in order to re-assume control. He called it repetition-compulsion and claimed that it is present in the lives of adults, e.g. in compulsive behaviours, and in the lives of small children - in play (Freud, 1959). Janet Murray, while proposing a new genre, cyber drama, which was to be a story enacted in a digital game, claims that one of the most important features of the genre is narrating through constant repetitions (Murray, 2000). Jesper Juul (2013) argues that failure and improvement, and not an easy win, are the things players actually seek in games. He writes: "the feeling of escaping failure (often by improving our skills) is central to the enjoyment of games" (p. 7).

Coming back and reliving lives once lived is crucial to video games. And we do not only do that to change the narrative - we do that to win, to master the game, and ultimately to fully control its world. The possibility of doing so relies on the impermanence of death in video games. On the level of mechanics, usually, these are the mechanics of save and autosave that allow the player to die, learn, come back, change, and win. However, not all games allow their players to come back. Some limit the player's ability to repeat any chosen passages or the whole game.

\section{Permadeath and beyond}

Jenova Chen (as cited in Isbister, 2016, pp. 4-6), while applying Mihaly Csikszentmihalyi's concept of flow to digital games, argues that the optimal moment of flow depends both on the difficulty of the game and on the player's skills. A game which is too easy is boring; and the more skilled the player is, the more challenging the game needs to be to still be engaging. One of the mechanics of making a game more difficult and thus more enjoyable is permadeath. In the permadeath game or permadeath mode, when the character dies, they die altogether and the player is forced to start the game all over again. It is popular in hardcore modes of action-RPGs (e.g., Diablo III), sports games, and arcade games. Although the player cannot go back to the exact moment of their death, 
they can master the game through repetitions. It is just harder and more frustrating, but it provides the players with a technical challenge.

There are players so skilled and blasé that even permadeath does not keep them interested. Upsilon Circuit and One Life tried to employ the extreme measure of permapermadeath - the mechanics of dying permanently in the world of the game and not being able to access it anymore. Upsilon Circuit was cancelled, and One Life has been "delayed indefinitely" (Grayson, 2016). Permapermadeath did not fulfill players' needs. It is financially unsatisfying (it leaves players who paid for the game with nothing, so it is most suitable for free games), but more importantly it fails the players who want the game to be difficult enough to be gripping but who also wish to be able to repeat it, master it and, ultimately, control it.

Nonetheless, permapermadeath and similar mechanics have their place in the world of digital games. They are used in many successful games for a different reason than creating a technical challenge. By severely delimiting or even denying the possibility of repeating the game experience, they make the events in a game matter, making them emotionally charged. This War of Mine employs a few mechanics of limiting repetitions. The game itself does not use permapermadeath; the player can replay it as many times as they want. However, there is no saving and coming back which means that all choices in a single game are permanent. Replaying the game does not guarantee a redemption, either, as a lot depends on the events randomly triggered through the game. The partial inaccessibility of the same events and passages gives the game some gravitas and makes our first choices (probably, first tragic mistakes) memorable. Later, after replaying the game multiple times, the player may grow indifferent towards its emotional appeal and play it to explore the game world and beat the game, but the first hours of playing send a powerful message that is hard to forget.

The boardgame Pandemic Legacy: Season 2 employs more permanent death mechanics. The game itself can be played once, as the board, the manual, and other items are updated during the game; the players explore the world and add stickers with new regions to the board, they build structures, enhance their characters by adding stickers with new abilities to their cards, etc. The characters may die permanently, which requires writing their place of death on the card, and the game itself can be lost. 
Changing the outcome of the game with such death mechanics is impossible. The games with save mechanics that allow the player to come back and re-live a chosen passage also allow the player to overwrite the narrative and choose which version of it they would consider a true part of the story (Kubiński's palimpsest trial). Pandemic Legacy does not allow this. The player could buy a new copy of the game that was lost, replay it, and convince themselves that the second version of the narrative is the true one. However, the palimpsest trial would be outside the game, as it is not written in the game mechanics. Replaying is, therefore, bending the rules, and it is harder to suspend the disbelief for the second outcome of the game.

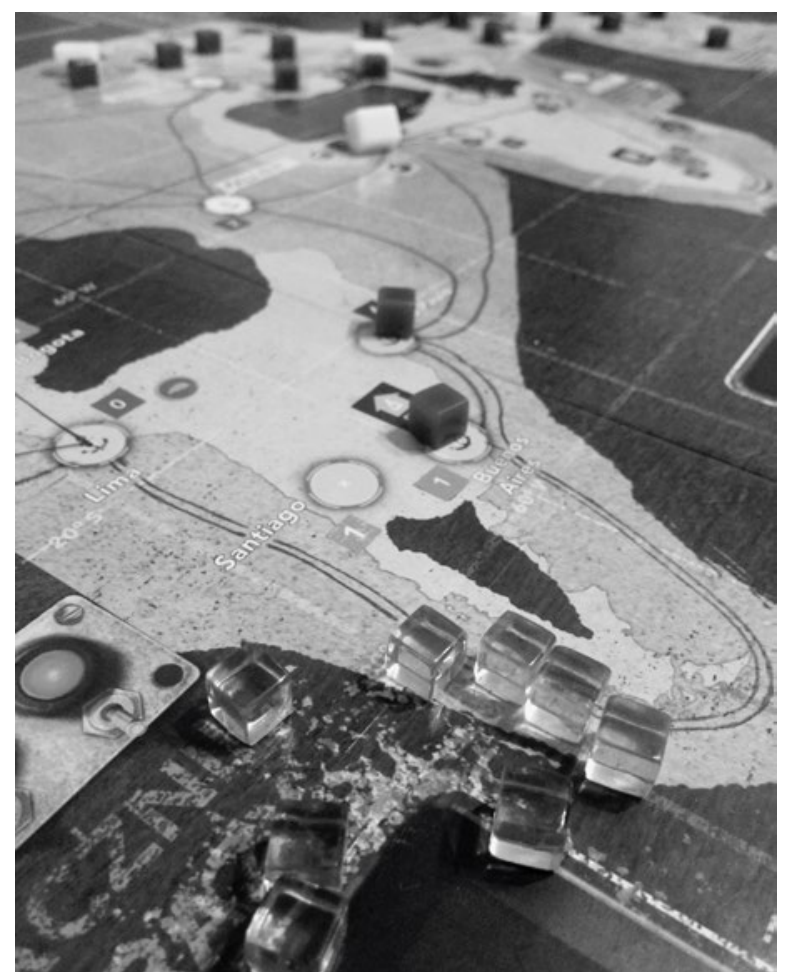

a. Pandemic Legacy: Season 2. The board

One Hour One Life, a new and already famous game by Jason Rohrer, employs more advanced mechanics of limiting possible repetitions. In each session, the player is reborn into the world, born to their mother another player - in a random place on the game map. They have one hour to live their life. What they will be able to do depends on the place 
where they are born - some are born in the jungle and some in the middle of a bustling town, in an organised community. The game has been operating since the 27th of February 2018. Every week Jason Rohrer adds some new features; the idea behind it is recreating the progress of human civilization - hour by hour, life by life.

The first experience in One Hour One Life is a series of short, colourful, fragmentary lives. The beginning is hard; the player has to survive in the unknown world and experience its miracles and dangers. Playing the game, I was born many times, and many times I died in infancy. Once of yellow fever. Many times because of starvation, abandonment, or the animals of prey. In one of the lives, my family dressed me in a wolf skin and called me wolfboi. In another, I was supposed to collect roots and berries, but I died of a rattlesnake bite. Finally, I reached adulthood and had children. I named them. I taught them. I saw their deaths. I experienced all that with strangers whom I will never talk to again. But I can still live another life. With time, I became less and less attached to the characters in the game and the events mattered less to me as they started to be repetitive. The game can be mastered with repetitions. No passage, no situation, no character will come back exactly the same, and it is hard even to find the same places in one of the next games; but the game remains open and after multiple sessions players are able to learn its rules - and be more powerful in the game world.

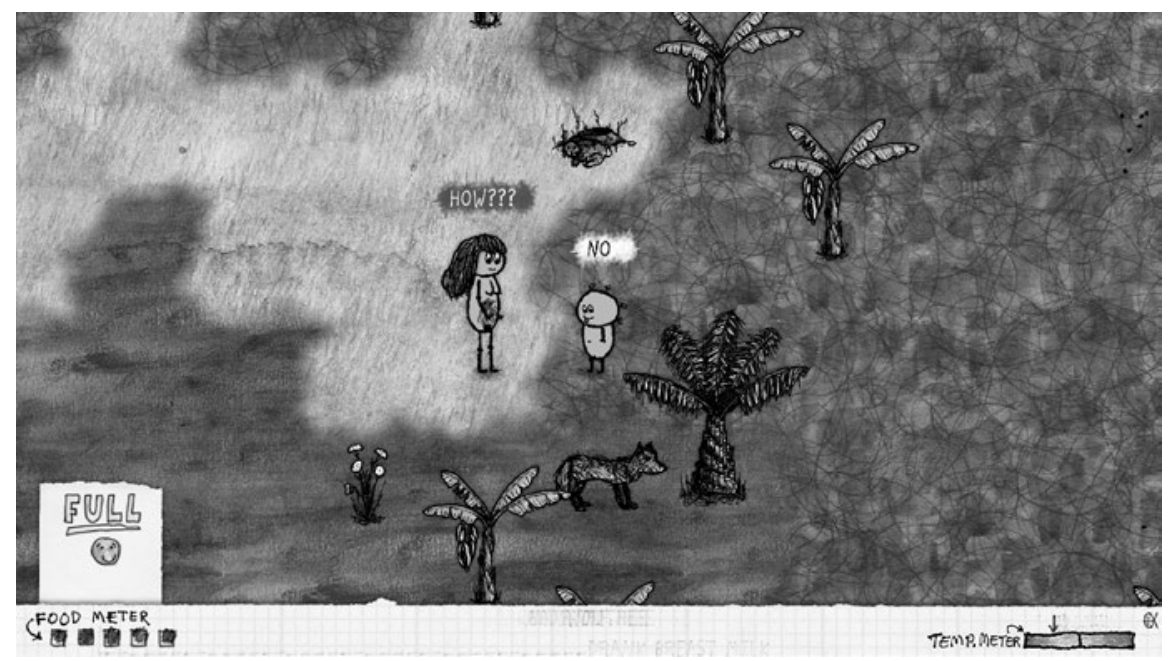

b. One Hour One Life. An untimely goodbye 


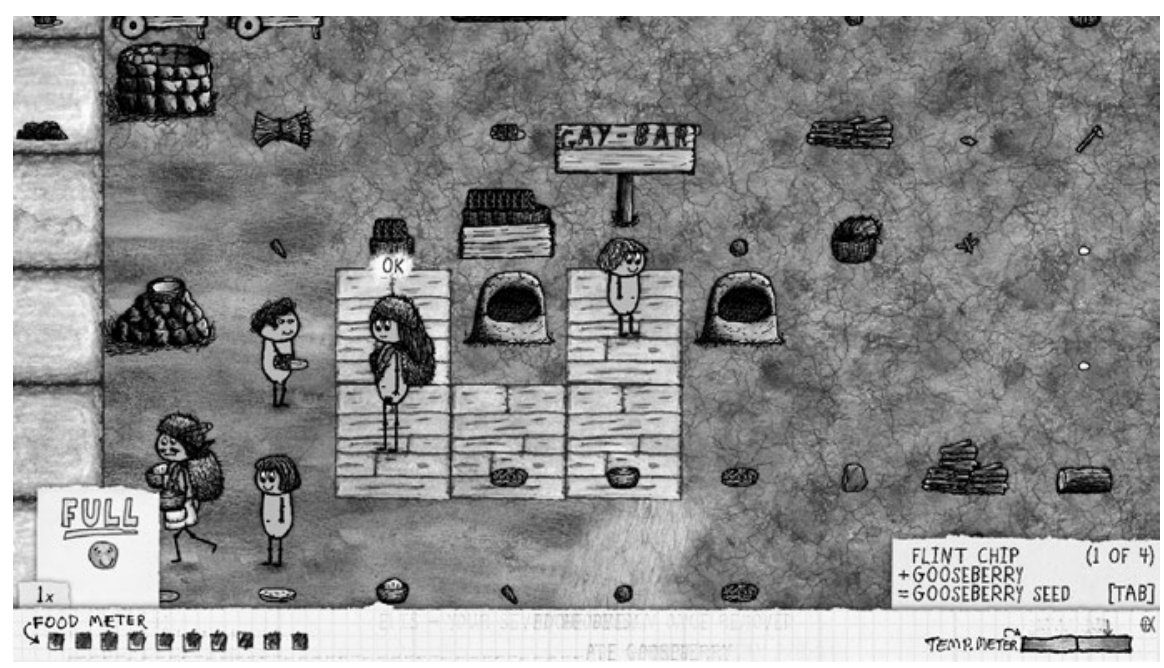

c. One Hour One Life. Structures built by players

Another, older game by Jason Rohrer, The Castle Doctrine, limits the player's ability to repeat the game in a similar way as One Hour One Life. It is about building a home, protecting it from others, and robbing other players. This is how he describes it:

Everything is real in this game. When you rob someone, you are actually hurting another player in a permanent way by destroying and stealing their hard work. When someone dies in this game, they lose everything and start over. If you devise perplexing security systems, you can perma-death other players when they come to rob you. (Rohrer, n.d., emphasis mine.)

"Perma-death" here means permapermadeath - a player who dies while robbing another player's home cannot play on the same server anymore; they are excluded from the game. It makes robbing others, of course, more exciting. The realness that Rohrer mentions seems to be the absence of palimpsest trial. It is mostly possible to come back to the game and experience similar events, both in The Castle Doctrine and in One Hour One Life, but the actions in the games are permanent. Whatever is done, is done. The narrative is one with the gameplay. There is no possibility of changing the narrative using non-narrative mechanics.

Up to this point, hardly any game has tried to stop players from replaying it even once. There are, however, rare games of this kind. The ones 
that I want to mention here are Doki Doki Literature Club and One Chance. Doki Doki is a game seemingly similar to a Japanese dating simulator. The protagonist joins an after-school writing club and he is supposed to choose one of the female members of the club and pursue a relationship with her. Everything goes well till the point when the game starts to employ episodes of violence very much out of the expected overly sweet esthetics and begins to glitch heavily. All that brings the player to the realisation that the game is, in fact, playing them. One of the girls, Monica, is self-aware and able to change the code of the game in order to push other girls out of the player's reach. Her goal is simple: she wants to be the one and only love interest of the player (not the character, of whose fictionality she is fully aware).

Ultimately the game reaches the point where Monica turns off everything except for herself and an empty room for her to sit in and wait for us. Every time we start the game, she will be there still. But the game is not finished yet. The player can choose to let Monika be or to delete her file from the game files. The second option triggers one of three possible endings, depending on the player's previous actions in the game ("Possible Endings"). The ending, whatever it may be, is permanent, though; the end screen will still be shown when the player enters the game. The only possibility to relive it is to reinstall it.

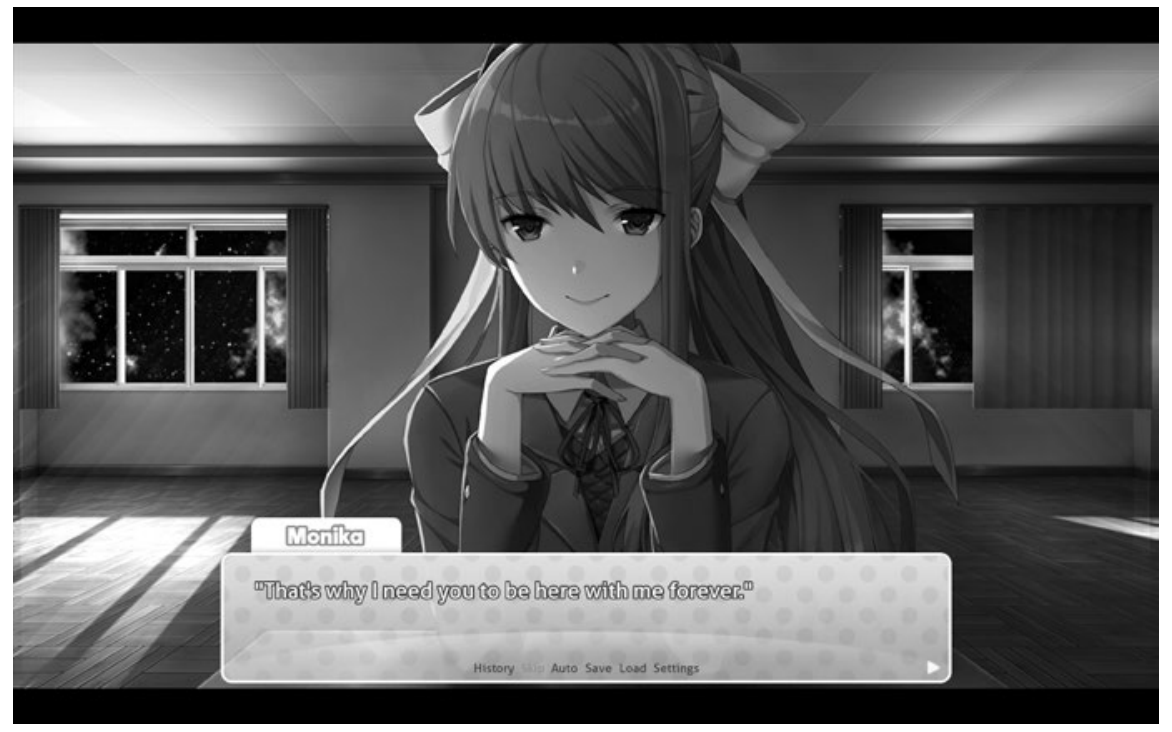

d. Doki Doki Literature Club. Monika in her forever room 
One Chance, a browser game created by Dean Moynihan, tries to stop the players from replaying it unless they manage to disable the cookies or enter the game on another computer. The plot of One Chance fully explains the use of these unusual mechanics. The protagonist is a scientist who has discovered a revolutionary cure for cancer. Just after releasing the drug it becomes clear that it will kill all life on Earth in six days. The player has a chance to reverse the effect - one chance, meaning both that they can try only once, and that there is only one happy ending. After finishing the game, the end screen displaying the ending the player has reached (in the majority of cases, quite tragic) will still be there any time they visit the game again.

The supposedly happy ending is the one in which the scientist discovers the cure and goes to the park with his daughter. The player's success is problematic, however, as all other characters are gone; humanity might be gone, and it is unknown whether the father and the daughter have survived, as they both look very sick and it is quite possible that they are already dead. The world is decaying; the brownish trees and the gray sky are most probably the signs of doom. Some time after playing, the end screen changes; discovering it requires coming back to the game after a long period of time. The view of a dying park and the father and daughter (or their bodies) sitting on a bench changes to an empty bench in front of the rich greenery of the trees. The Earth has been saved, then. The protagonist's and the girl's status is unknown. Maybe they have both survived. Maybe he is alive but she has died and he has buried her. Maybe they have both died, but the planet is still alive. The last ending seems to be the one justified by the mechanics of the game. The world still exists but the consciousness which was the vehicle allowing the player to experience this world is gone.

\section{Perma-dying worlds}

One Chance mixes two departures from the most popular game mechanics. First, it does not allow the player to save and load the game, so the narrative is perfectly linear, with no palimpsest trial possible. Second, it employs permapermadeath, so the player can experience the game 
only once - therefore the narrative is not only linear but unique as well: it cannot be repeated and overwritten in the memory of the player by another rendering of events. These two altered mechanics are essentially a matter of one key difference between One Chance and other games: in One Chance the player loses control over time.

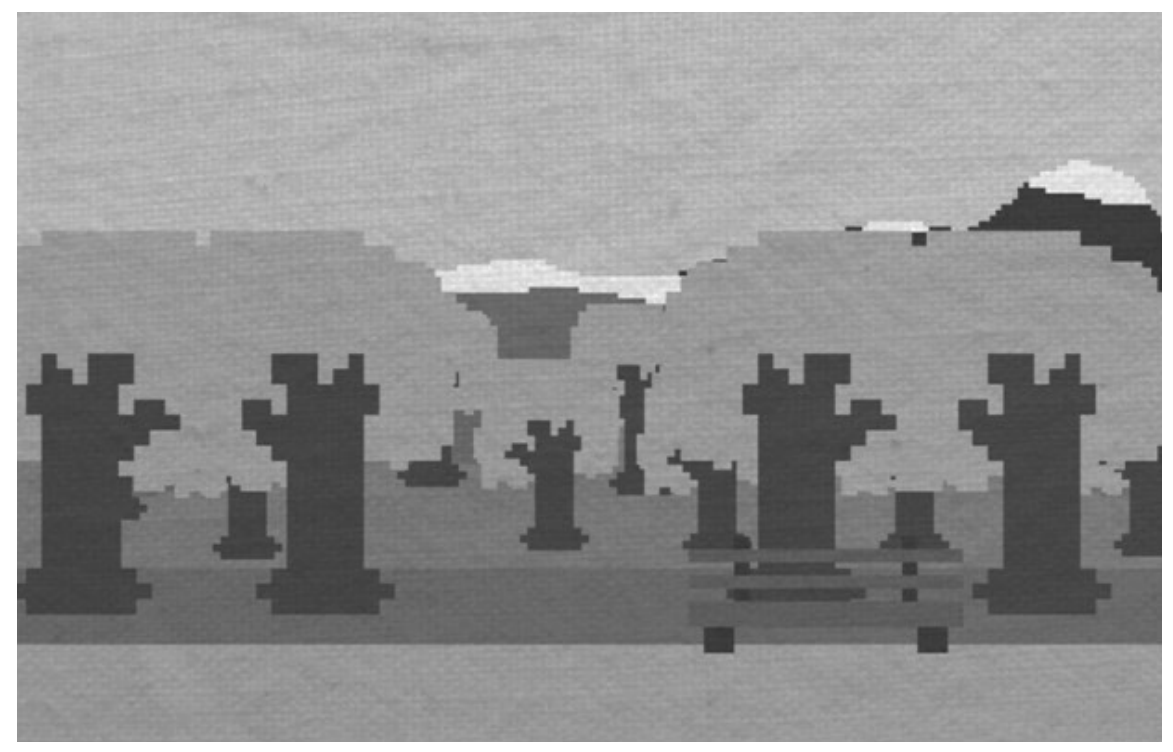

e. One Chance. The second end screen of the game

And control over time means control over the outcome of the game. By reenacting traumatic events we can enact control over their results and regain some part of control. By believing in the ideas of eternal recurrence or afterlife, we can escape grief over things long lost, or possibilities long gone. Games that grant the player control over time are very comforting too; in fact, they are like multiple afterlives, one after another, shaped by choices made differently and challenges tackled better than before. Jane McGonigal said that the very real possibility of rising up to the challenge empowers players, making them more confident and willing to make a change (McGonigal, 2010). One of the major appeals of games is power. Yet, a lot of games limit this power. Most games do so either to make the struggle more challenging and thus pleasurable (e.g. games with permadeath), or to engage the player and make them care about the narrative, or both of these things (like This War of Mine, 
Pandemic Legacy: Season 2, One Hour One Life). Jesper Juul (2013) notices that "we are motivated to play when something is at stake" (p. 13) and that failure in a game that does not allow us to repeat the same events, e.g. in a multiplayer, results in "permanent loss" (p. 14). The uniqueness of the experience makes the game and its narrative matter more. This is what Rohrer calls realness - the narrative and mechanics are one, and whatever happens in the narrative cannot be changed on the level of mechanics. The possibility of rising up to the challenge is smaller but winning so much more satisfying and worth fighting for (Rohrer, n.d.).

Games using permapermadeath do not only limit the players' control, they take it away completely. Mastering the game through repetitions is impossible; the only ergodic quality of the game that is left is choice. In the case of Doki Doki Literature Club and One Chance this choice is blind. It is hard to guess how the choices in the game will influence the ending, and even the best intentions and skills do not guarantee the good result. Afterwards, the games use end screens to haunt the players with what they did and what they did not manage to do. While most games cater to the fear of powerlessness, here control is almost completely gone.

Experiencing powerlessness, despite the importance of empowerment, may be beneficial, though. Reinhold Niebuhr wrote: God, grant me the serenity to accept the things I cannot change, courage to change the things I can, and wisdom to know the difference (as cited in Shapiro, 2008). Ole Fogh Kirkeby expanded his thought and defined positive powerlessness as "the ability to distinguish between that which is in our power, and that which is not, with the consequence to be able to act properly." "This is the zone of practice", he added ("Pragmageton, The leadership of events," n.d.). Perma-dying worlds grant players the possibility to learn how to experience powerlessness. They have to make choices, try to achieve a good result and accept that they may be really out of control, which probably is much easier in fiction that it is in real life, and evokes less guilt. The outcome is frustrating only if we believe we could have done better; therefore the ultimate quest, instead of mastering the game, is letting go.

Why would anybody decide to experience powerlessness, though? Why small free games, like Doki Doki Literature Club, or One Chance, have such a big audience? Jesper Juul (2013) in his book The Art of Failure describes 
the paradox of failure: if we avoid failure in life, and games make us fail, then why do we play games in which we experience something we would otherwise avoid? (p. 33). Juul compares the paradox of failure to the paradox of painful art, which goes as follows: if we avoid painful emotions, and some art evokes them, then why do we want to experience art that causes the very same emotions we would normally escape? These paradoxes have three possible explanations: that we do not really care about failure in games and pain in art (which is not true), that failure and pain are compensated, and the third possible explanation - an a-hedonistic one - that we do not always seek pleasure (Juul, 36-37, 2013).

The third explanation seems to be the most important one when it comes to games that almost inevitably lead to both failure and painful emotions. Freud described repetition-compulsion as an exception from the pleasure-seeking that he previously thought solely governs our lives. In repetitions, painful experiences are re-enacted in a controlled way. They are still painful, but repeating them on one's own terms helps in regaining control and surviving trauma.

In some situations, we are ready to fail. Especially when it is a guiltfree failure, like catching a cold or having moderately bad luck. The reason for the suffering is arbitrary, and these small misfortunes give us a permission to take care of ourselves, to rest, to ask for help, to treat ourselves better - a permission that we would otherwise not give ourselves. Perma-dying worlds are arbitrary, too. Victory in One Chance does not reward skills or the investment of time. Winning or losing is just a chance. Failure comes guilt-free, but in a chosen time, and it brings feelings that we would often evade: a cathartic sadness, a therapeutic grief.

\section{References}

Csikszentmihalyi, M. (2008). Finding flow. New York, NY: Basic Books. Doki-doki-literature-club.fandom.com Possible Endings. Online: <https:// doki-doki-literature-club.fandom.com/wiki/Possible_Endings $>$. Freud, S. (1959). Beyond the pleasure principle. New York, NY: Bantam Books. Gooding-Williams, R. (2011). The death of Nietzsche's Zarathustra [Review of the book The Death of Nietzsche's Zarathustra]. Notre Dame 
Philosophical Reviews. Retrieved from $<$ https://ndpr.nd.edu/news/thedeath-of-nietzsche-s-zarathustra/>.

Grayson, N. (27 ${ }^{\text {th }}$ October 2016). One year later, those two perma-permadeath games aren't doing so great. Online: <https://kotaku.com/ one-year-later-those-two-perma-permadeath-games-arent-1788301072>. Isbister, K. (2016). How Games Move Us. Cambridge MA: MIT Press. Jayisgames.com (16 $6^{\text {th }}$ December 2010). One Chance - Walkthrough, Tips, Review. Online: <https://jayisgames.com/review/one-chance.php>. Juul, J. (2013). The art of failure: An essay on the pain of playing video games. Cambridge MA: MIT Press.

Kirkeby, O.F. (no date). Pragmageton, The leadership of events. Online: <https://www.cbs.dk/files/cbs.dk/ofkspeech3rdmarch.pdf>.

Kubiński, P. (2016). Gry wideo. Zarys poetyki. Kraków: UNIVERSITAS.

Loeb, P. (2010). The death of Nietzsche's Zarathustra. Cambridge: Cambridge University Press.

McGonigal, J. (2010). Gaming can make a better world [Video]. Online: $<$ https://www.ted.com/talks/jane_mcgonigal_gaming_can_make_a_better_world\# t-603894>.

Meer, A. (2010). One Chance, 1470 Words. Retrieved from <https: www. rockpapershotgun. com/2010/12/13/one-chance-1470-words/>.

Murray, J. (2000). Hamlet on the holodeck: The future of narrative in cyberspace. Cambridge MA: MIT Press.

Nietzsche, F. (2014). Tako rzecze Zaratustra. Poznań: Wydawnictwo Zysk i S-ka.

Rohrer, J. (no date). The Castle Doctrine. Online: <https://store.steampowered.com/app/249570/The_Castle_Doctrine/?l=danish\&curator_clanid $=2669017>$.

Shapiro, F. (2008). Who Wrote the Serenity Prayer? Online: <http:// archives.yalealumnimagazine.com/issues/2008_07/serenity.html>.

Date of access to all online sources: $24^{\text {th }}$ December 2018 .

\section{Ludography}

11bit Studios (2014). This War of Mine [multi-platform]. 11bit Studios, Poland.

Blizzard Entertainment (2012). Diablo III [multi-platform]. Blizzard Entertainment, US. 
Leacock, M. and R. Daviau. (2017). Pandemic Legacy: Season 2 [boardgame]. Asmodee and Z-man Games, US.

Moynihan, D. (2010). One Chance. [online]. Awkward Silence Games, England. Retrieved from <https://www.kongregate.com/games/LemmiBeans/one-chance>.

Rohrer, J. (2018). One Hour One Life [PC, iOS]. Jason Rohrer, US.

Rohrer, J. (2014). The Castle Doctrine [PC, iOS]. Jason Rohrer, US.

Team Salvato (2017). Doki Doki Literature Club [PC, iOS]. Team Salvato, US.

All the photos and screenshots from the games were taken by me.

Eleonora Imbierowicz, M.A. - a Ph.D. student at the Institute of English Studies, University of Wroctaw

\title{
Światy, które umierają na zawsze. Granica wiecznego powrotu w grach cyfrowych
}

\begin{abstract}
Abstrakt: Artykuł omawia rodzaje śmierci w wybranych grach cyfrowych i planszowych, dzieląc gry na dwie grupy: te, które pozwalają graczom powracać do swoich światów niezliczoną ilość razy i realizują w ten sposób ideę wiecznego powrotu, oraz te, które ograniczają liczbę możliwych powtórzeń. Artykuł skupia się na tych drugich, opisując mechaniki ograniczające dostęp do treści gry - począwszy od permadeath, poprzez losowość i jednorazowość przeżyć w wybranych grach typu multiplayer online, aż do permapermadeath - $\mathrm{i}$ analizując skutki ich stosowania.
\end{abstract}

Stowa kluczowe: permapermadeath, permadeath, wieczny powrót, mechaniki śmierci 